\title{
Inactivation of infectious salmon anaemia virus, viral haemorrhagic septicaemia virus and infectious pancreatic necrosis virus in water using UVC irradiation
}

\author{
Ann Kristin Øye, Espen Rimstad* \\ Department of Pharmacology, Microbiology and Food Hygiene, Norwegian School of Veterinary Science, \\ PO Box 8146 Dep., 0033 Oslo, Norway
}

\begin{abstract}
The UVC irradiation doses necessary for a 99.9\% (3-log) inactivation of 3 different fish pathogenic viruses diluted in freshwater/seawater and wastewater from a fish processing plant were determined. The results showed that both infectious salmon anaemia virus (ISAV) and viral haemorrhagic septicaemia virus (VHSV) were very sensitive to UVC irradiation, showing a 3-log reduction of infectivity in freshwater of $33 \pm 3.5$ and $7.9 \pm 1.5 \mathrm{~J} \mathrm{~m}^{-2}$, respectively, while that of infectious pancreatic necrosis virus (IPNV) was substantially higher, $1188 \pm 57 \mathrm{~J} \mathrm{~m}^{-2}$. Using ISAV as a model, a comparison of the effect of UVC irradiation on virus isolation versus reverse transcription polymerase chain reaction (RT-PCR) showed that considerably higher UVC doses, depending on the length of the amplified product, were necessary to abolish RT-PCR detection of viral RNA.
\end{abstract}

KEY WORDS: UVC inactivation - Infectious salmon anaemia virus · Infectious pancreatic necrosis virus · Viral hemorrhagic septicaemia virus

Resale or republication not permitted without written consent of the publisher

\section{INTRODUCTION}

Viral diseases have a great impact on the fish farming industry mainly because methods of treatment are not available and because vaccination is not yet feasible at the early life stages of fish, when these diseases may cause high mortality. Avoiding contact between the fish and the pathogens may thus be the only available control measure. In the farming of Atlantic salmon Salmo salar L. there are several viruses that can cause significant mortality. Among the most important viral agents are infectious salmon anaemia virus (ISAV), viral haemorrhagic septicaemia virus (VHSV) and infectious pancreatic necrosis virus (IPNV). Control of the incoming water to a hatchery is essential in minimising the exposure of farmed salmon to infectious agents throughout the freshwater part of the life cycle.

${ }^{*}$ Corresponding author. E-mail: espen.rimstad@veths.no
There are several methods to perform this control, but short-wave ultraviolet irradiation, either alone or in combination with other disinfectants, is widely used. Ultraviolet irradiation is divided into 3 regions according to its wavelength: UVA (400-320 nm), UVB (320$280 \mathrm{~nm}$ ) and UVC (280-200 nm), of which UVC has the most germicidal effect. UVC is effectively absorbed by ozone in the earth's atmosphere, but can be artificially produced. There are no known undesirable by-products when UVC irradiation is used, and it has been shown to be an effective method for the inactivation of bacteria and viruses (Kurth et al. 1999). The biological effect of UVC irradiation is mainly caused by its effect on DNA and RNA (Cadet et al. 1992). In the RNA viruses, such as ISAV, VHSV and IPNV, UVC irradiation causes dimerisation of uracil units, leading to mutations or breaks in the genome, and high doses may also cause formation of protein-RNA covalent linkages (Smirnov et al. 1991). Both these modes of 
action are responsible for virus inactivation. The effect of UV on inactivation of micro-organisms depends on the dose, which is defined as intensity times exposure time. Infectious salmon anaemia is observed in Atlantic salmon during the seawater period. However, many hatcheries add seawater to their incoming freshwater for $\mathrm{pH}$ stabilisation; therefore the disease has probably also been found in hatcheries (Nylund et al. 1999). In Europe, viral haemorrhagic septicaemia mainly occurs in freshwater-farmed rainbow trout, but has also been found in marine fish, and there are probably reservoirs of VHSV in marine fish species (Mortensen et al. 1999). Infectious pancreatic necrosis in farmed Atlantic salmon occurs frequently in fry, but also in smolts shortly after transfer to seawater.

There are regulatory requirements for treatment of wastewater from hatcheries and salmon abattoirs. The water should be cleared of pathogens as infectious agents may pose a risk for farming downstream of the outlet or for marine farming. However, wastewater, especially from abattoirs, has a high content of proteins and particulate materials that may influence the effect of the disinfectants.

The purpose of the present work is to examine the effect of UVC on the viability of the ISAV, but also for VHSV and IPNV, both in water resembling incoming water to hatcheries and in wastewater from salmon abattoirs. Two methods - virus isolation in cell culture and RT-PCR - were compared in order to determine the occurrence of ISAV following UVC irradiation.

\section{MATERIALS AND METHODS}

Viruses and cells. The ISAV strain Glesvaer/2/90 was used (Dannevig et al. 1995). This virus was cultivated in salmon head kidney cells (SHK-1) using Leibovitz L-15 medium supplemented with foetal bovine serum $(5 \%)$, glutamine $(4 \mathrm{mM}), 2$-mercaptoethanol $(40 \mu \mathrm{M})$, and gentamicin $\left(50 \mu \mathrm{g} \mathrm{ml}^{-1}\right)$ as the growth medium. The VHSV, Voldbjerg strain, DK9592B, was grown in blue fry gill cells (BF2), while IPNV, serotype $\mathrm{Sp}$, isolate Rauma, was grown in $\mathrm{BF} 2$ and chinook salmon embryo cells (CHSE-214). The cell culture medium for BF2 and CHSE was minimum essential medium with Earl's salts (EMEM) with foetal calf serum $(10 \%)$, glutamine $(4 \mathrm{mM}), \mathrm{NaHCO}_{3}(0.045 \%)$, hepes $(15 \mathrm{mM})$, and gentamicin $\left(50 \mathrm{\mu g} \mathrm{ml}^{-1}\right)$. Cell cultures were maintained at $20^{\circ} \mathrm{C}$, but incubated at $15^{\circ} \mathrm{C}$ after the virus was inoculated. Prior to irradiation all virus solutions were quantified by measuring the tissue culture infective dose $\left(\mathrm{TCID}_{50} \mathrm{ml}^{-1}\right)$ by end-point titration.

Virus assays. Virus infectivity was determined by endpoint titration in 96-well culture plates. To avoid toxic effect on the cells, the inoculum was removed and fresh medium added after $1 \mathrm{~h}$ for the wastewater suspensions. For VHSV and IPNV, cytopathic effects (CPE) were evaluated after $1 \mathrm{wk}$, while ISAV was quantified by immunocytochemical staining $5 \mathrm{~d}$ post inoculation using the ISAV specific monoclonal antibody 3H6F8 and peroxidase labelled secondary antibody (Falk et al. 1998).

UVC irradiation. Eleven UVC-emitting low-pressure mercury lamps (HNS-OFR 30W, Osram, Munich, Germany; wavelength $253.7 \mathrm{~nm}$ ) horizontally suspended in a laminar airflow sterile bench were used as the UVC source.

The UVC irradiation was measured in $\mathrm{J} \mathrm{m}^{-2}(1 \mathrm{~J}$ $\mathrm{m}^{-2}=100 \mu \mathrm{W} \mathrm{s} \mathrm{cm}{ }^{-2}$ ) with a radiometer (UVX; UVP Inc. Upland, CA, USA) at the same distance from the UVC source as the test solution. UVC radiation is shortwaved, and therefore the penetration is low.

Viruses were suspended in freshwater and in wastewater obtained from a fish processing plant. The wastewater was collected at the fish processing plant after the first filtration and kept in dark at $4^{\circ} \mathrm{C}$. The turbidity of the wastewater was found to be 200 FNU (formazine nephelometric units) measured according to the ISO standard 7027 - 'Water quality; Determination of turbidity'. (Drinking water from surface water should ideally have a turbidity of less than 0.1 FNU.) In addition, ISAV was suspended in seawater (35\% salinity). The freshwater and seawater were autoclaved prior to use, while the wastewater was irradiated 15 min before the virus was added.

Irradiation was performed on a $15 \mathrm{ml}$ virus suspension in a $5 \mathrm{~cm}$ Petri dish. The time elapsed from the start of irradiation to sampling was different for each virus and dependent on the solution used to suspend the virus. The sample volume was 200 to $250 \mu \mathrm{l}$ for each sampling. In each experiment, a sample of nonUV irradiated test virus was taken to determine the initial $\mathrm{TCID}_{50} \mathrm{ml}^{-1}$, as well as a sample of the solution without the virus to test for possible harmful effects of the solution to the cells. Experiments were done at room temperature, and samples were kept on ice until processed. All experiments were replicated at least 3 times, with 4 parallels each time, and the data are reported as averages with standard deviations. The $\mathrm{TCID}_{50} \mathrm{ml}^{-1}$ of the non-irradiated and irradiated samples were used for calculation of the 3-log reduction.

To calculate the effective irradiance received by virus particles, the $\mathrm{OD}_{254}$ (the wavelength of UVC transmitted from the lamps is $253.7 \mathrm{~nm}$ ) of the different virus solutions was determined. The connection between irradiation $(I)$ and absorbance $(A)$ is given by the following formula (derived from Lambert-Beer's law): $I=$ $I_{0} 10^{-A_{254} \times d}$, in which $I_{0}$ is the irradiation measured and $d$ is the depth of the solution. The depth of the solution 
was $0.74 \mathrm{~cm}$ prior to sampling, and $0.37 \mathrm{~cm}$, half of this depth, is where on average the virus would be in the solution. The potential interaction due to shadowing of the walls of the Petri dish was minimised by continuously slowly stirring the suspension with a magnetic stirrer $(10 \mathrm{~mm} \times 3 \mathrm{~mm})$ and collecting samples from the centre of the dish. Furthermore, by testing for the shadowing effect of the walls in a Petri dish, a $4 \%$ reduction in irradiance was found (M. M. Bråthen et al. pers. comm.), giving a correction factor for the dish $\left(C_{\text {dish }}\right)$ of 0.96. Similarly, only the irradiation from incoming angles between $-35^{\circ}$ and $35^{\circ}$ contributed to the measured irradiation (M. M. Bråthen et al. pers. comm.), and the reflection in this range is approximately $3.0 \%$, giving a correction factor for reflection $\left(C_{\text {refl }}\right)$ of 0.97 . The average irradiance received by virus particles in our system was therefore calculated to be $I_{\text {avg }}=C_{\text {dish }} \times$ $C_{\text {refl }} \times I_{0} \times 10^{-A_{254} \times 0.37}=0.93 \times I_{0} \times 10^{-A_{254} \times 0.37}$.

The wastewater had an $\mathrm{OD}_{254}$ of approximately 2.5 , which was above the range for accurate absorbance determination. Therefore, the dose emitted and not the average dose absorbed by a virus particle was measured for samples in wastewater. The results from the wastewater irradiation experiments thus cannot be compared directly with the results from the freshwater and seawater irradiation experiments.

Polymerase chain reaction (PCR) assays. For ISAV, in addition to an infectivity assay, PCR was performed. The heart, liver and spleen were harvested from Atlantic salmon presmolts with an average weight of approximately $40 \mathrm{~g}$. The fish were cohabitants from a tank in which 5 of 125 fish had been given an intraperitoneal injection containing $0.3 \times 10^{3} \mathrm{TCID}_{50}$ of ISAV. The organs were homogenized in diethyl pyrocarbonate (DEPC $;$ an RNase inhibitor) treated phosphate buffered saline (PBS) $(10 \times$ volume $)$ in sterile plastic bags, using a roller. This homogenate was diluted 1:100 and centrifuged for $10 \mathrm{~min}$ at $3000 \times \mathrm{g}$. The supernatant was then removed and UVC irradiated as described above. The $\mathrm{OD}_{254}$ of the supernatant was approximately 2.5 . After irradiation, samples of $350 \mu$ l were removed and RNA was isolated using the $\mathrm{RNeasy}^{\circledR}$ miniprep kit (Qiagen, Valencia, CA, USA) according to the manufacturer's recommendations. In the subsequent RT (reverse transcription)-PCR reactions, $1 \mu \mathrm{g}$ RNA was used. One-step RT-PCR was carried out using ReadyTo-Go ${ }^{\circledR}$ RT-PCR Beads (Amersham Pharmacia, Uppsala, Sweden) with random hexamers (pd $[\mathrm{N}]_{6}$ Amersham Pharmacia) as primers for the cDNA synthesis. The cDNA synthesis was carried out for $30 \mathrm{~min}$ at $42^{\circ} \mathrm{C}$. Different ISAV-specific primer pairs were used to amplify products of different lengths (Mikalsen et al. in press). The primer sets were as follows: Primer set 1: GGCTATCTACCATGAACGAATC and GCCAAGTGTAAGTAGCACTCC ; length of product: $155 \mathrm{bp}$. Primer set 2: ACTTGGGAACCAATGACTGC and CTTCACCGAAAAACCGGTAA; length of product: $194 \mathrm{bp}$. Primer set 3: GGCTATCTACCATGAACGAATC and GGGCTTTCGAACTCGACTCC; length of product 507 bp. Primer set 4: GGCTATCTACCATGAACGAATC and CCAAATATCCCATTCAACAC; length of product 890 bp. To avoid nonspecific reactions during cDNA synthesis, the ISAV-specific primers were added after the cDNA synthesis was terminated, while the tubes were kept on ice. Cycling conditions were $94^{\circ} \mathrm{C}$ for 5 min followed by 35 cycles of $94^{\circ} \mathrm{C}$ for $30 \mathrm{~s}, 55^{\circ} \mathrm{C}$ for $15 \mathrm{~s}$ and $72^{\circ} \mathrm{C}$ for $30 \mathrm{~s}$ and a final extension at $72^{\circ} \mathrm{C}$ for $7 \mathrm{~min}$. For the primer sets that yielded products longer than $500 \mathrm{bp}$, the synthesis time was increased to $1 \mathrm{~min}$. PCR products were resolved by electrophoresis on a $3 \%$ agarose gel and visualized under UV light after ethidium bromide staining.

\section{RESULTS AND DISCUSSION}

The dose response curves of the effect of UVC irradiation on virus infectivity, measured as virus titre in TCID $_{50}$, are shown in Fig. 1. There was an exponential fall in virus titres with increasing doses of UVC irradiation; however, minor deviations from this were observed when wastewater solutions were irradiated.

Both VHSV and ISAV were very sensitive to UVC irradiation and showed a 3-log reduction of infective virus in freshwater at a UVC dose of $33 \pm 3.5 \mathrm{~J} \mathrm{~m}^{-2}$ and $7.9 \pm 1.5 \mathrm{~J} \mathrm{~m}^{-2}$, respectively. These results are consistent with a previous estimate of $90 \%$ (1-log) reduction of VHSV after a dose of $1 \mathrm{~J} \mathrm{~m}^{-2}$ (Maisse et al. 1980). VHSV and ISAV are ssRNA viruses, belonging to the Rhabdoviridae and Orthomyxoviridae, respectively, and UVC inactivation data of other ssRNA viruses are in agreement with our findings. For example, infectious haematopoietic necrosis virus (Rhabdoviridae) showed a 3-log reduction after a UVC dose of $20 \mathrm{~J} \mathrm{~m}^{-2}$ (Sako) and Newcastle disease virus (Paramyxoviridae) had an estimated 3-log reduction in water after a dose of 20 to $30 \mathrm{~J} \mathrm{~m}^{-2}$ (von Brodorotti \& Mahnel 1982). A higher UVC dose was required for a 3-log reduction of ISAV in seawater $\left(51 \pm 13 \mathrm{~J} \mathrm{~m}^{-2}\right)$ than in freshwater $\left(33 \pm 3.5 \mathrm{~J} \mathrm{~m}^{-2}\right)$. However, the reasons for this remain obscure.

The irradiation dose necessary for a 3-log reduction of IPNV in freshwater was substantially higher than for ISAV and VHSV. For IPNV, a 3-log reduction was obtained after a UVC dose of $1188 \pm 57 \mathrm{~J} \mathrm{~m}^{-2}$, which is a 30-40 and a 120-140 times higher dose than the dose required for ISAV and VHSV, respectively. Other investigators have reported somewhat higher doses than observed in the present study for the reduction of IPNV in water. These investigators reported 1000-1500 and 

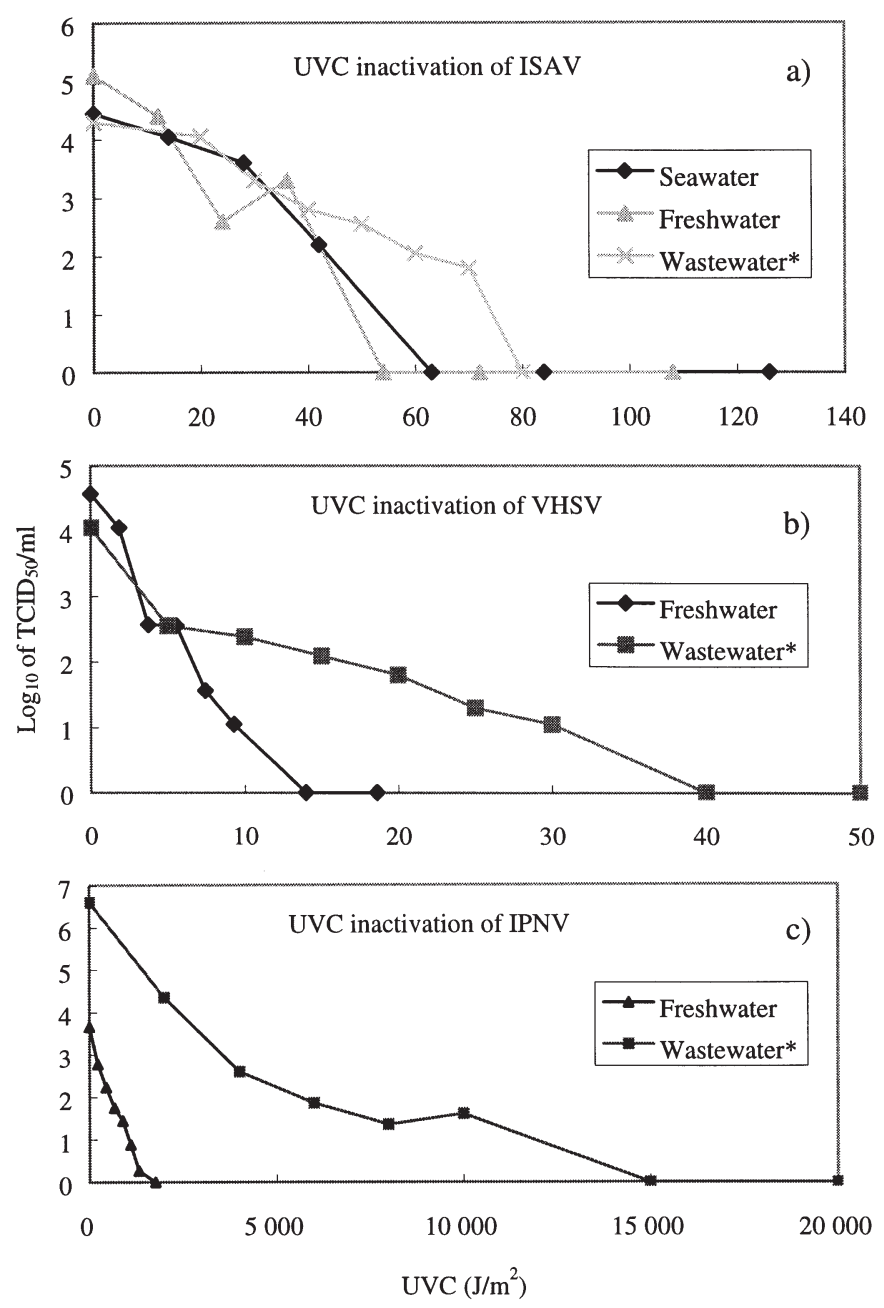

Fig. 1. Dose response curves showing UVC-irradiation effect on virus infectivity in different aqueous solutions. (a) ISAV; (b) VHSV; (c) IPNV. *For wastewater the total emitted dose is shown

1500-2000 $\mathrm{J} \mathrm{m}^{-2}$ for 2-log and 3-log reductions, respectively (Ahne 1982, Sako \& Sorimachi 1985). Another dsRNA virus, chum salmon virus (CSV, Reoviridae), is reported to show a 2-log reduction at an UVC-dose of about $1000 \mathrm{~J} \mathrm{~m}^{-2}$ (Yoshimizu et al. 1986). Viruses with single-stranded nucleic acids are less resistant to UVC irradiation than viruses with doublestranded nucleic acids, and the longer the singlestranded genome, the easier the virus is to inactivate by UVC (von Brodorotti \& Mahnel 1982). The small dsRNA genome of IPNV may thus explain its substantial difference in UVC irradiation resistance to that of ISAV and VHSV. The genomic ssRNA of VHSV consists of a single molecule of approximately $11 \mathrm{~kb}$, and ISAV has an ssRNA genome of $14.5 \mathrm{~kb}$. Although the ISAV genome is divided into 8 segments ranging in size from 0.9 to $2.3 \mathrm{~kb}$ (Mjaaland et al. 1997), the genome size alone does not explain the differences in UVC resistance found between ISAV and VHSV.

When the virus suspensions were mixed with the wastewater from the fish processing plant, the doses emitted to obtain 3-log reductions in $\mathrm{TCID}_{50}$ of ISAV, VHSV and IPNV were $72 \pm 16,31 \pm 1.8$ and $3367 \pm 275$ $\mathrm{J} \mathrm{m}^{-2}$, respectively. In wastewater, higher resistance to UVC was expected considering the high turbidity in the samples, as particulate material in the solution would lower the transmittance of UVC rays (Schoenen et al. 1991). The number, size and UVC transmittance of the particles have an impact on the disinfection effect of UVC. The $\mathrm{OD}_{254}$ of the solution was approximately 2.5, and according to the formula given in 'Materials and methods', the average UVC dose that is absorbed by the virus would be only about one-tenth of the emitted dose. Correcting for this, the UVC dose absorbed by the virus particles in wastewater, and necessary for a 3-log reduction in infectivity of the different viruses, would be 2.5 to 5 times lower than in freshwater. An explanation for this may be that viruses easily become attached to particulate materials in aquatic environments (Yoshinaka et al. 2000), which can result in lower virus titres, as measured in endpoint dilution, as the viruses may not be evenly distributed in the sample but aggregated to particles.

The results from RT-PCR of irradiated tissue homogenate from salmon with experimental ISAV infection showed that complete removal of positive RT-PCR results required much higher UVC doses than removal of infectivity. An 890 bp amplicon was still detectable after a UVC dose of $1750 \mathrm{~J} \mathrm{~m}^{-2}$, but after $2000 \mathrm{~J} \mathrm{~m}^{-2}$ no such product could be detected. A $507 \mathrm{bp}$ amplicon was detectable after a UVC dose of $5000 \mathrm{~J} \mathrm{~m}^{-2}$, but not after $6000 \mathrm{~J} \mathrm{~m}^{-2}$. Smaller amplicons, of 155 and $194 \mathrm{bp}$, were still detectable after a UVC dose of $50000 \mathrm{~J} \mathrm{~m}^{-2}$. At such high doses, it was difficult to estimate the endpoint at which no positive RT-PCR could be achieved. These results indicate that a positive ISAV RT-PCR result cannot be interpreted as equal to the detection of a viable virus. For the smallest amplicon used in this study, $155 \mathrm{bp}$, the sensitivity of the RT-PCR has been estimated to be between 0.01 and 0.1 TCID $_{50}$ of ISAV (Mikalsen et al. in press). The size of that amplicon is approximately $1 / 100$ of the ISAV genome, and if only a single break in the genome would abolish infectivity, a UVC dose of $10^{3}$ to $10^{4}$ higher magnitude would be necessary to abolish that RT-PCR than to abolish infectivity. A complete abolition of positive RT-PCR results would not only require breakage of the genome between the primers, but also of mRNA and cRNA copies present in the tissue; even overlapping cDNA targets could be sufficient to re-establish the PCR. Furthermore, the possibility that the amplified segment contains sequences that will give dimerisation of uracil 
units after UV exposure is determined by the length and nucleotide sequence of the segment. The possibility that the segment contains nucleotide sequences that will cause RT-PCR termination after UV exposure increases with increasing size of the segment. In conclusion, the use of UVC irradiation could be beneficial for the inactivation of the ssRNA viruses ISAV and VHSV in the inflow water to hatcheries. However, the UVC dose needed to inactivate IPNV would be very high. Even in aqueous solutions with high turbidity, UVC irradiation is still efficient. However, high absorbance and turbidity are hindrances when estimating the doses absorbed by the virus particles. This could cause significant problems if UVC were used for inactivation of viruses in wastewater.

Acknowledgements. This study was supported by grant no. 126986/213 from the Norwegian Research Council and by Klean ASA. The technical assistance from Berit Gamnes is appreciated.

\section{LITERATURE CITED}

Ahne W (1982) Comparative studies of the stability of 4 fishpathogenic viruses (VHSV, PFR, SVCV, IPNV). Zentbl Vetmed Reihe B 29:457-476

Cadet J, Anselmino C, Douki T, Voituriez L (1992) Photochemistry of nucleic acids in cells. J Photochem Photobiol B 15:277-298

Dannevig BH, Falk K, Namork E (1995) Isolation of the causal virus of infectious salmon anaemia (ISA) in a long-term cell line from Atlantic salmon head kidney. J Gen Virol 76: 1353-1359

Falk K, Namork E, Dannevig BH (1998) Characterization and applications of a monoclonal antibody against infectious

Editorial responsibility: Jo-Ann Leong,

Corvallis, Oregon, USA salmon anaemia virus. Dis Aquat Org 34:77-85

Kurth J, Waldmann R, Heith J, Mausbach K, Burian R (1999) Efficient inactivation of viruses and mycoplasma in animal sera using UVC irradiation. Dev Biol Stand 99:111-118

Maisse G, Dorson M, Torchy C (1980) Inactivation of two viral pathogens of salmonids. Bull Fran Piscicult 278:34-40

Mikalsen AB, Teig A, Helleman AL, Mjaaland S, Rimstad S (in press) Detection of infectious salmon anaemia virus (ISAV), by RT-PCR after cohabitant exposure in Atlantic salmon (Salmo salar 1.) Dis Aquat Org

Mjaaland S, Rimstad E, Falk K, Dannevig BH (1997) Genomic characterization of the virus causing infectious salmon anemia in Atlantic salmon (Salmo salar L.): an orthomyxolike virus in a teleost. J Virol 71:7681-7686

Mortensen HF, Heuer OE, Lorenzen N, Otte L, Olesen NJ (1999) Isolation of viral haemorrhagic septicaemia virus (VHSV) from wild marine fish species in the Baltic Sea, Kattegat, Skagerrak and the North Sea. Virus Res 63: 95-106

Nylund A, Krossoy B, Devold M, Aspehaug V, Steine NO, Hovland T (1999) Outbreak of ISA during first feeding of salmon fry (Salmo salar). Bull Eur Fish Pathol 19:70-74

Sako H, Sorimachi M (1985) Susceptibility of fish pathogenic viruses, bacteria and fungus to ultraviolet irradiation and the disinfectant effect of UV-ozone water sterilizer on the pathogens in water. Bull Natl Res Inst Aquacult 8:51-58

Schoenen D, Zemke V, Kolch A (1991) Effect of the reflection of UV rays in the disinfection of drinking water. Zentbl Hyg Umweltmed 191:396-405

Smirnov YA, Kapitulets SP, Amitina NN, Ginevskaya VA, Kaverin NV (1991) Effect of UV-irradiation on rotavirus. Acta Virol 35:1-6

von Brodorotti HS, Mahnel H (1982) Comparative studies on susceptibility of viruses to ultraviolet rays. Zentbl Vetmed Reihe B 29:129-136

Yoshimizu M, Takizawa H, Kimura T (1986) Susceptibility of some fish pathogenic viruses. Fish Pathol 21:47-51

Yoshinaka T, Yoshimizu M, Ezura Y (2000) Adsorption and infectivity of infectious hematopoietic necrosis virus (IHNV) with various solids. J Aquat Anim Health 12:64-68

Submitted: February 16, 1999; Accepted: August 16, 2001

Proofs received from author(s): November 22, 2001 